\title{
Carbon and Biodiversity Conservation as Resource Extraction: Enacting REDD+ Across Cultures of Ownership in Amazonia
}

\author{
Marc Brightman
}

\section{INTRODUCTION}

Forest carbon and biodiversity are increasingly measured and quantified with a view to improving their management as valuable resources, often with a view to engaging market mechanisms to improve cost-efficiency. If such resources are being 'marketised', in what ways does this process differ from conventional resource extraction such as logging or mining? Indigenous peoples, especially those for whom the forest is a home and 'biodiversity' is an abstract substitute for a world of everyday relations, can offer important insight into this question.

This chapter is a revised and updated version of texts previously published in French in Ethnographiques (Brightman 2014), and in Portuguese, in RURIS (Brightman 2016a). It is based primarily on research carried out during 2010-12 thanks to a Marie Curie Intra-European Fellowship at the Graduate Institute in Geneva.
M. Brightman ( $\square)$
University College London, London, UK
e-mail: m.brightman@ucl.ac.uk
(C) The Author(s) 2019
C. Vindal Ødegaard, J. J. Rivera Andía (eds.), Indigenous Life
Projects and Extractivism, Approaches to Social Inequality and
Difference, https://doi.org/10.1007/978-3-319-93435-8_8 
The concept of biodiversity emerged at the historical interface between the biological sciences and politics (Maris 2010). It is of particular interest to examine the politics of biodiversity in a country such as Suriname, which is part of the highly biodiverse Guayanan ecoregion (Olson and Dinerstein 1998), and has exceptionally extensive forest cover (90 per cent [FAO 2010]). Perhaps precisely because of this great abundance, the concept of biodiversity has little interest for most Surinamese people and is certainly not an electoral issue. Members of the majority urban, coastal population, if they express an opinion about the forest at all, tend to say there is too much of it, and their attitude towards people who live there tends to be of fear, contempt, or a mixture of both. There is a strong correlation between ethnic identity and habitat: descendents of freed slaves (Creoles) and indentured labourers (Hindustanis, Javanese, and others) are concentrated in the capital city of Paramaribo and on the narrow coastal strip that has been developed for agriculture and industry, whereas the inhabitants of the vast forested interior of the country are mostly Maroons and Amerindians. The former are descendents of runaway slaves who escaped Dutch plantations in the seventeenth century to form new tribal societies (Price 2011: 10). The Amerindians, the original inhabitants of the region, include a number of Carib and Arawak groups. For most Maroons and Amerindians, 'biodiversity' is not a meaningful category, but the variety and wealth of game animals, and useful plants, trees, and other species that are found in the forest play a fundamental part in their lives, not only in terms of subsistence but also as sources of meaning; what urban people call 'nature' is for them the theatre in which what we might call 'culture' is played out.

Some of the same things can be said about the other 'natural' or 'primary' resources of Suriname: goods such as gold, bauxite, or timber are found in the 'wild' interior (binnenland), and they are similarly coveted by international interests. The quantity of such resources is uncertain because of the limited amount of surveying that has been carried out, and this uncertainty can suggest a hitherto unexploited abundance. Extractive activities, therefore, rarely excite anxieties over resource scarcity, whether in the case of artisanal placer mining, of industrial timber or mining concessions, or of the thriving informal trade in bushmeat. Like mineral resources, it is widely assumed that the sources of tasty paca (Agouti paca), aimara (Hoplias aimara), or caiman (Caiman crocodilus) meat will long continue to provide their bounty. The perception of the forest's abundance, even excess, makes it hard to imagine otherwise. And the technical specialists (generally staff of conservation NGOs with training in conservation biology 
or geography appropriate for biodiversity surveying) who attempt to quantify new resources like forest carbon and biodiversity find that it is an even more difficult and complicated task than the quantification of conventional ones like gold or bauxite. ${ }^{1}$

Widespread indifference does not prevent the forest from having substantial political importance in Suriname, which arises from two quarters, both of which have significant international dimensions: these are, firstly, the increasingly close ties between development aid and concern for environmental sustainability, as a result of growing institutional recognition of global ecological crisis (Adams 1990; Sachs 2015) and, secondly, the rise to political prominence of the indigenous peoples' movement. This should be seen against the background of Suriname's recent history. Following independence from Holland, in 1975, the political situation rapidly declined, and the 'interior' was neglected until a military coup took place in 1980, of which one of the instigators, Desi Bouterse, quickly rose to prominence and became President two years later. The new regime began to institute a development programme for the interior, but this was short lived, because an Ndjuka Maroon, ${ }^{2}$ Ronnie Brunswijk, who had been a member of Bouterse' personal guard, began to form his own military unit in the east of the country, and a series of raids and reprisals led to a descent into full-scale civil war. As a consequence of this 'war of the interior', the interior of Suriname, especially the Maroni River basin in the east where the majority of the Maroon population lives, was neglected to the extent that some have described it as a 'stateless zone' (Jolivet 2007; Kruijt and Hoogbergen 2005). When the fighting ended with a peace agreement, a coalition government agreed to an International Monetary Fund structural adjustment programme in 1991 and tried to attract foreign investment in the forestry and mineral sectors. But the postwar stability was short lived: the opposition party won the 1996 elections bringing Bouterse to power again, and the economy fell into decline together with diplomatic relations with Holland-the main aid donor and former colonial power (Kambel and Mackay 1999: 13). The state meanwhile granted concessions in the interior (while some areas have been exploited outside its control, notably for gold), giving rise to conflict over land rights with wide-ranging implications, as I shall discuss in greater detail below (see also Price 2011).

In November 2011, I interviewed the Minister of Physical Planning, Land, and Forest Management of Suriname, together with his immediate entourage, about the changing stakes in the relationship between the government and the country's indigenous peoples in relation to land. One 
official with several decades of experience emphasised two things. The first was the fact that, the Amerindians ('Indianen'), who are becoming increasingly well organised politically, are putting pressure on the government to recognise their rights to land, making claims apparently in tension with evidence that some Amerindian communities are overexploiting their forest resources to sell garden produce for cash, in order to build large houses and purchase consumer goods. The second was that in the southern part of Suriname, where there are no roads and scarcely any other infrastructure, Suriname's genetic resources are, according to him, being plundered. $\mathrm{He}$ gave the example of the dyeing dart frog, Dendrobates tinctorius, which, he claimed, existed at first in Suriname alone, and which is now 'spread out' around the world due to clandestine trading. The Amerindians are being paid disproportionately small sums of money for these creatures, which command much higher prices abroad. But the most serious problem, he argued, is that Suriname loses its sovereignty over the genetic resources that are synthetically altered in foreign countries and then patented.

My own field research confirms that the Trio, a Carib-speaking people who live on the Sipiliwini Savannah on Suriname's southern border with Brazil, do trade in a number of species of live animals (including species of Dendrobates), for which they are paid small amounts in relation to international prices. ${ }^{3}$ In this border region, it is unlikely that many species are unique to Suriname, and the Dendrobates tinctorius can, in fact, be found in other parts of the Guiana shield region. I am not sure how serious a problem foreign gene patenting really is for Suriname. But what strikes me here is the way in which the government officials spontaneously and emphatically linked the matters of land rights, biodiversity, and national sovereignty. In this chapter, I show that the value of land for a native Amazonian people is also linked to biodiversity and sovereignty but in different ways: rather than conceiving land separately from its nonhuman inhabitants, the Trio value land in terms of the relations between the living actors that dwell there.

\section{LAND Rights}

Indigenous claims to land rights are often perceived as being in conflict with state sovereignty. But the nature of legal rights is such that the opposite may be argued: " "the right to land" in most cases ... [entails the right to] a certain territorial area embedded within a state. This condition renders many of indigenous peoples' rights conditional upon the wider 
national entity wherein they reside, plus the status of the latter within the international community' (Westra 2008: 23). It is to a significant extent due to its postcolonial history of war and corruption that Suriname has become the only country in South America never to have passed any kind of land reforms in favour of its indigenous peoples (whose situation is generally considered alongside the larger Maroon groups legally categorised as 'tribal peoples'). In recent years, it has come under increasing pressure to do so. This pressure comes from the internationalisation of campaigns for indigenous and tribal rights, through initiatives coming from both within and outside Suriname. Two of these appear especially significant. The first is the successful campaign of the Saramaka Maroons for compensation over environmental damage and the displacement of communities due to the construction of the Afobaka Dam in their territory. This led to the landmark ruling (Saramaka v. Suriname judgement) of the Inter-American Court of Human Rights of 28 November 2007, which declared that Suriname had violated the rights of the Saramaka People. The ruling declared that Suriname must seek the Saramaka's prior and informed consent for any intervention that might threaten their sexistence as a tribal people, highlighting that 'land is more than merely a source of subsistence; it is also a necessary source for the continuation of the life and cultural identity of the Saramaka people' (para 82) (Orellana 2008: 842). The Court thus puts Suriname under pressure to accept and adopt its interpretation of customary international law, based on an understanding of culture as land, which envisions a communal conception of property (Engle 2010: 167). ${ }^{4}$

The second initiative is REDD+ (Reduce Emissions from Deforestation and forest Degradation in developing countries), the emerging UN-sponsored mechanism for 'reducing emissions from deforestation and degradation "plus" conservation, sustainable development of forests, and improvement of carbon stocks' (IUCN 2012), for which the Surinamese state has been in the process of preparing since 2009. This programme can be understood as a giant system of payments for ecosystem services, similar to the carbon offsetting that constitutes most of the existing 'voluntary' market in forest carbon. ${ }^{5}$ Its founding principle is that countries that preserve or increase their forest cover should be paid for the opportunity $\operatorname{costs}^{6}$ of doing so. It involves a set of 'safeguards', including provisions for the protection of forest peoples from abuses such as land grabs (these provisions' effectiveness is a contentious subject). In March 2013, Suriname's 'readiness preparation proposal' (R-PP) for REDD+ was approved by the 
World Bank's Forest Carbon Partnership Facility, allowing Suriname to receive USD 3.8 million for technical preparations for joining the REDD+ mechanism, scheduled to come into force in 2020. The R-PP was severely criticised by Suriname's indigenous and tribal representatives and by the international indigenous rights advocacy organisation, Forest People's Programme (FPP), for making disingenuous claims about the consultation process and about guarantees to address and protect indigenous and tribal land tenure (FPP 2013).

The 'readiness' process in preparation for REDD+, taking place shortly after the Saramaka ruling, provided the context for short-lived land rights negotiations between the government of Suriname and its indigenous and tribal peoples. When I visited the secretariat of the VIDS (Vereniging van Inheemse Dorpshoofden in Suriname) indigenous leaders' organisation in the summer of 2011 , its members were excitedly preparing for a longawaited government conference on land rights for Amerindians and Maroons. When this took place in October 2011, the VIDS representative gave an opening speech, which set out the organisation's demands for full recognition of indigenous rights to land. President Desi Bouterse, the former military dictator who had returned to power by popular vote in 2010 , reacted by summarily closing the conference on the grounds that the agreed protocol for discussion had not been observed. Further negotiations have been promised but have not so far taken place even following a landmark ruling by the Inter-American Court of Human Rights in 2015 on the case of the Kali'na and Lokono of the lower Maroni River, whose livelihoods were severely affected by a bauxite concession granted in 1958 (Namati 2015).

REDD+ takes on different characteristics according to the actors who are imagining it. For politicians, it represents a further opportunity to capture international funding, ostensibly for the nation, but often (as history shows) for personal gain. For Amerindian and Maroon leaders and other individuals sufficiently aware of the issues, it is at best a doubleedged sword and something to be treated with extreme caution: while it may offer an opportunity to increase the pressure for state recognition of customary land rights and seems to invite further international scrutiny of the practices of national institutions, it may also create perverse incentives for outsiders to attempt to disenfranchise them still further. For conservation NGOs, there seems little doubt: the prospect of REDD+ reinforces their role as technical and research specialists in the field of forest governance. 


\section{Ownership in Amazonian Societies}

Indigenous leaders are likely to be correct in thinking that the prospect of REDD+ makes it still more urgent for them to secure their land titles; indeed, speculation over the potential value of forest for carbon sequestration has already led to land grabs in other parts of Amazonia (FPP 2012). At the same time, the conditions of REDD+ place governments under pressure to recognise these rights (Sommerville 2011). But indigenous land rights debates nearly always take place in terms quite foreign to indigenous systems of property relations. Until recently, the idea of property was even absent or confined to footnotes in most Amazonian ethnography. In the last few years, along with a handful of colleagues, I have been trying to explore native Amazonian forms of ownership (Brightman et al. 2016; Costa 2010; cf. Guzmán-Gallegos this volume). Contrary to received wisdom, the concept of ownership is present in many, if not all, aspects of native Amazonian cosmologies (Brightman 2010). Fausto compares Kuikuro ownership to Marilyn Strathern's idea of the magnified person, according to which the single entity represents and encompasses the group category: in this sense, leaders personify their villages as well as being their 'owners', and the spirit masters of game animals are the personifications and 'owners' of the species (Fausto 2008). ${ }^{7}$ Among the Kanamari, the concepts of owner and body are conflated, and Luiz Costa traces the owner-body-chief concept through a nested hierarchy 'from living bodies, to village chiefs, to the chiefs of river basins' (2012). In my own work, I have emphasised the processual nature of ownership in Amazonia (Brightman 2010, 2016a, b) ${ }^{8}$ Objects become property by virtue of having been transformed or made by their owners. The clearest and most important example of this is the swidden, which is appropriated from the forest to become the property of the gardener; after a swidden is abandoned, it gradually reverts to being the property of nobody in particular as it is reclaimed by the forest.

The processual nature of kinship has received a great deal of attention in Amazonian ethnography, and it is through it that the two perspectives on property described above, emphasising mastery and transformative processes, respectively, meet. Fausto's discussion of ownership builds on his analysis of familiarising predation, that is, the process by which outsiders can be adopted by turning them into asymmetric consanguines in the form of children or pets. Similarly, in her ethnography of the Trio, Vanessa Grotti has described the nurturing or feeding processes involved in domesticating 
enemy groups - this can be seen as the 'work' of appropriation in the sphere of kinship (Grotti 2007; cf. the 'care' described by Rivera, this volume). The transformation of forest into garden, similarly, is a process of domestication. As has been widely documented in Amazonia, garden plants are nurtured and cared for as kin. Similarly, pet animals, which are called by kinship terms and fed human food (especially manioc bread) are frequently game animals and are often juvenile offspring of animals that are taken in the hunt. Ownership and appropriation of nonhumans occur in the idiom of kinship; the appropriation of forest, and thus the revaluation of 'land', occurs through the cultivation of domesticated plants-it is an act of domestication in itself, as the domestication of place. ${ }^{9}$

The vectors of ownership and appropriation do not always overlap. In an article which successfully blurs Philippe Descola's distinction between Amazonian societies that relate to nonhumans through predation and through reciprocity (1992), Peter Rivière notes that the Trio do not simply regard all animals, or even all game animals, as having spirit masters (2001). He contrasts three Trio myths in which a shaman encounters nonhuman animals. In the first two, which involve a spider monkey and a tapir, respectively, the shaman only meets the animals themselves, not the spirit master of the species in question. They do not communicate successfully, their relationship is characterised by mistrust, and the humans and animals end by predating upon each other. In the third myth, the shaman meets the master of white-lipped peccary, and they enter into a ceremonial dialogue. The peccary master agrees to release peccary for humans to hunt, although he warns that the peccary will steal from the humans' gardens. As Rivière notes, the Trio regard peccary as a more sociable species than tapir or spider monkey. They are related to in a human way through their spirit master, and a relationship of reciprocity ensues. It seems to me that a similar logic applies to land. The Trio relate to different places in a more sociable, or reciprocal way, or a more predatory way, according to the level of sociability, or humanity, of those places.

\section{Trio Property Relations}

The Trio are composed of a number of different groups, which came to live in mission stations in the mid-twentieth century and began to intermarry. Little more than 2000 in number, they live on both sides of the international border between Suriname and Brazil. They live mainly from swidden horticulture - their main crop being bitter manioc-as well as 
hunting, fishing, and gathering, but some Trio have paid employment and others trade forest products. As a result, they are increasingly part of the cash economy.

The Trio distinguish two basic categories of land: first, there is the cleared space of the village, pata, or garden, tëpitë. Second, there is the forest, $i t u$. The way of being in each spatial category is differentiated linguistically through the use of two different postpositions: - po, and -tao. Although both of these postpositions could be translated as 'in', pata-po ('in the village'), or tëpitë-po ('in the garden'), both draw attention to the fact of being in a humanised, culturally transformed place, while itubtao ('in the forest') suggests being located within a physical medium or environment. It is significant that the postposition -tao is also used for water, or the river- 'in the water or river' is tunabtao. The aquatic realm is the quintessential domain of spirits and other mythical beings and is even more plainly associated with alterity than the forest. The distinction between these two kinds of space mirrors property relations. Swiddens, tëpitë, are owned by individual families; itu, 'forest', is not owned by human persons, and neither is the water. A village is owned by its leader, who is also literally referred to (among other things) as pata entu, village owner.

However, seen through time, the distinction between these kinds of space and their status in terms of ownership is not so clear. New swiddens tend to be cut in places where the forest has reclaimed abandoned swiddens over time. The same applies to villages: when a new village is created, the best places for building are said to be those in which people dwelt in the past. In fact, the two processes are connected: when new villages are created, they begin as a garden with a house in it, and it is partly because gardens tend to be relocated more frequently than villages that the two categories, garden and village, become separated, as new gardens are cut further away from the houses.

Trio people do not consider old gardens and old villages to be the property of particular families. They are recognised as 'appropriable', as potential spaces for human habitation and cultivation because they bear the marks of human action. The markers of previous domestication include domestic plant species-manioc, fruit trees, and so forth-as well as other signs such as petroglyphs and rocks marked by grooves where they were used for sharpening tools. They are places which were transformed by humans in the past and thus appropriated, but the traces of individual identity have disappeared. A process of forgetting thus ensures that such places are not monopolised by particular families. Anne-Christine Taylor 
has already drawn our attention to the importance of forgetting the dead in Amazonian societies (1993). But what I want to underline is that such places are not entirely 'wild' - the marks of human habitation and exploitation identify them as generically buman places. If the process of transforming land for cultivation is an act of appropriation, it is highly significant that it is not permanent. Yet this should be seen in the context of a notion of territory, in which Trio people regard themselves as free to cultivate, hunt, and fish and to manage their own affairs independently-as such, they have sovereignty in this territory.

\section{VALUing RELATIONS}

David Graeber proposed creating a theory of value 'starting from the assumption that what is ultimately being evaluated are not things, but actions' (Graeber 2001: 49). It seems to me that the Trio, when they 'value land', do not value a thing but sets of actions and relations. As I have tried to show, the value of land for the Trio is explicitly relational. The anthropology of property has tended to define property as relations between persons with respect to things (Hann 1998). But, here, it seems that property relations are relations between persons, full stop. The mastery or ownership relation structures the status of a garden as property of its creator in the same way as a leader is master-owner of his village and as a spirit master is owner of an animal or plant species. As the myths of the peccary, the tapir, and the spider monkey suggest, the appropriation of resources from the environment is a matter of interpersonal predation or reciprocity. The preparation of meat for consumption entails the return of the prey animal's soul matter to the forest, and the gardens are left open to encourage nonhuman animals, including game animals, to feed on the crops. There is no objective value of a given piece of land because its value changes through time. Its value is also created through time as the product of the nurturing processes of previous gardeners.

Meanwhile, value, ownership, and the act of appropriation do not necessarily map neatly onto one another. Certain wild species of plant are gathered, and they are certainly valued, although they are not 'owned' by humans; in such cases, it is not always obvious whether the appropriation of the products of these plants constitutes an act of predation or is involved in a relationship of reciprocity-this seems to vary from one species to another. As authors such as William Balée, Darrell Posey, and Laura Rival have shown (Posey and Balée 1989; Rival 2002), the distinction between 
wild and domestic species is often far from clear. But this matters little in practice because property is not treated as thoroughly exclusive-stealing from somebody's garden is not a serious offence, and in their ordinary lives, the Trio have little use for hard forms of 'property rights' ${ }^{10}$ to decide who can appropriate which resources at what time.

\section{Regimes of VALUe}

Despite their remote location in southern Suriname, far from roads and deep rivers, the Trio are not entirely isolated from the effects of state attempts to control resources and territory, international markets, or the politics of rainforest conservation. Considerable changes took place in their way of relating to the forest in the early 1960s as a result of the cutting of airstrips by the Surinamese army for the creation of mission stations, in parallel with an equivalent process on the Brazilian side of the border. Encouraged by the missionaries and attracted by the prospect of direct access to white people's trade objects (bypassing their Maroon trading partners), most Trio moved to live at these mission stations over a period of a few years. In fact, there were a number of different groups, such as the Okomojana, the Aramiso, the Piropï, and the Pirëujana, whose identities became submerged through this process of sedentarisation as they adopted the common language of Tarëno-literally, 'the people here'.

More recently, the Trio have been involved with two conservation NGOs, Conservation International (CI) and Amazon Conservation Team (ACT). The former has been involved in the region for many years and indeed dominates conservation in both Suriname and neighbouring Guyana (Chapin 2004). ACT was created by ethnobotanist Mark Plotkin when he left CI to pursue his own projects, giving greater emphasis to traditional knowledge and livelihoods, and grew out of his own field research in Suriname (Plotkin 1994). The main emphasis of CI has tended to be upon documenting biodiversity, while ACT takes a social entrepreneurship approach to promoting 'sustainable development' through markets and preserving traditional knowledge. Both have been involved in mapping projects. Using what are known as 'participatory methods', ACT has produced maps of traditional resource use, with the explicit purpose of providing evidence upon which to base land rights claims. This is highly significant in Suriname, which has so far not recognised or demarcated any indigenous or tribal territories (Kambel and Mackay 1999; Price 2011). Meanwhile, CI received a government mandate to produce a forest inventory map for 
the whole of Suriname, which they did using satellite technology (Gwendolyn Smith pers. comm. 2011). Also, near the largest Trio village of Kwamalasamutu, CI collaborated with the Trio to create two protected areas. One of these is based around wërepai, a petroglyph site which was discovered only recently, but which the Trio recognise as having been made by their ancestors. CI describes this as a 'sacred site' and claims that for this reason, the Trio agreed to impose hunting restrictions around it. The other area was created following an interesting exchange between the village leader Asonko (who is also the Trio Granman, or 'tribal' chief, a title conferred by the state [see Brightman 2016b]) and CI: according to the CI director, Asonko asked her for help to create a farm for game animals because the village had grown so large that overhunting had become a problem. She told him that it was impossible, but that, instead, she could help him make a restricted area for hunting to allow the animals to breed. The project went ahead and CI's monitoring suggests that it has been successful in preserving stocks of game animals.

The whole interior of Suriname is officially state property. The state does not recognise indigenous forms of ownership (cf. Guzmán-Gallegos, this volume) or even the capacity of Amerindians to manage their own protected areas. The only official conservation areas that exist are state managed with some responsibility delegated to NGOs. Although traditional swidden cultivation and hunting are allowed in these areas, swidden horticulture is officially regarded as a form of forest degradation and this misconception forms part of the rationale for refusing to recognise indigenous peoples' forest management capability.

When President Bouterse returned to power, in 2010, he announced that a memorandum of understanding had been set up with China for the construction of a road to the Brazilian frontier, and plans are underway to build a hydroelectric dam, which would flood some Trio, Wayana, and Maroon villages. It is for the purposes of preparing for REDD+ that the Surinamese government commissioned a forest inventory map from CI. The infrastructure projects of a road and dam would, of course, cause massive deforestation, which is highly significant for REDD+, because the payments that the government would receive under REDD+ are to be calculated in terms of opportunity costs, on the basis of alternative future development scenarios. In other words, the infrastructure plan, which, if executed, would cause deforestation and significantly increased carbon emissions, serves to manipulate the baseline for calculating REDD+ payments in terms of avoided emissions. As a result of all of this, the political 
situation between the government and forest peoples remains tense. Surinamese indigenous and Maroon organisations recognise that they must campaign for their land rights before consenting to any involvement in REDD+. The government also claims to accept that it will have to recognise indigenous land rights in order to qualify for REDD+ funding. The NGOs, CI, and ACT are playing the role of mediators and brokers, helping the government with technical procedures while trying to encourage it to recognise indigenous practices and at the same time trying to explain the REDD+ mechanism to both indigenous peoples and government staff.

\section{VALUE AND MARKETS}

REDD+ is catalysing the emergence of a new marketable commodity: forest carbon. Unlike previously existing carbon markets, which are based on emissions trading, forest carbon is based on the estimated value of the carbon emissions deemed to be avoided through conservation. One aspect of the 'plus' element of REDD+ is a biodiversity value. Without entering into debates about the competing definitions or criteria for measuring biodiversity, discussions of REDD + emphasise the latter's instrumental value as potentially commodifiable intellectual property and as a necessary component of ecosystem functioning. Such 'ecosystem service' values shadow the value of conventional natural resources-especially timber and minerals - as opportunity costs. This reflects the prevailing neoclassical assumption that markets will stabilise a 'correct' price for commodities (carbon, biodiversity) - a view that is contested by scholars who show how value in new markets is the product of a range of social interactions and the development of market infrastructures (Barman 2015; Callon 2009; Callon and Muniesa 2005).

These market calculations can only be made on the basis of accurate measurements of the resources and services in question: it is for this reason that the government has recruited a Dutch company to carry out a full survey for the proposed hydroelectric dam project, and that it commissioned CI to produce a national forest inventory. Indeed, while it is a standard practice to carry out surveys in advance of corporate mining or logging activities (leaving aside the important informal sector), the large-scale measurement of carbon and biodiversity stocks is something relatively new. Consequently, an important part of Suriname's REDD+ programme, as with other countries, is what is known as MRV-monitoring, reporting, and verification. Against the baseline of the forest inventory, national governments are responsible 
for putting in place technical capacity to monitor forest conservation, to report any deforestation or degradation, and to verify the government's official data. These activities are sometimes known for short as 'carbon accounting', and their importance is such that forest carbon (and similarly biodiversity) must be continually audited in order for them to have any kind of sustained and recognisable existence, and thus to have any political and economic effect.

It is worth noting here that the extraction of value from forests in the form of biodiversity and carbon depends upon the work of measurement and accounting in much the same way that the extraction of other resources depends upon the physical work of removal. But these are, of course, very different kinds of 'work', and it is debatable to what extent the marketisation of forest carbon and biodiversity amount to 'extraction' at all.

\section{PATHS AND MAPS}

The use of measurement and quantification techniques to value resources seems foreign to the Trio's relational mode of land use. Two different temporal modes are also at play here: for the Trio, a certain focus on the present is crucial for the forgetting of past ownership relations and for the cycle of abandonment and regeneration of garden sites to continue without causing tension. This is expressed in Trio kinship, which does not trace ancestry or genealogies, and does not even distinguish between consanguines and affines beyond two generations. In contrast, forest accounting requires accurate time measurement, for environmental services are meaningless without reference to their sustained provision through time. ${ }^{11}$

At this point, it may be worth distinguishing two forms of mapping activity: on the one hand, there is the documenting of traditional resource use through cartography for the purposes of land claims and the eventual demarcation of indigenous territories. On the other hand, there are various scientific surveying activities to quantify resources: forest carbon, biodiversity, game animals, timber, and subsoil mineral resources. The Trio themselves see these as virtually identical cultural processes of measurement and quantification. However, they do relate to them in different ways. ACT's map-making activities have been requested by Trio leaders themselves, and Trio individuals have participated in them in return for a small salary. CI's biodiversity surveys have always been CI's own initiatives, although they do also sometimes employ Trio people and solicit their input. CI's work has sometimes been regarded with suspicion by 
Trio, particularly biodiversity surveys that were carried out recently in the area likely to be affected by the planned hydroelectric dam. Some Trio people suspected CI of preparing to expropriate their land and working for the government to measure the resources that could be extracted before the dam would be built (in fact, it seems that CI was compiling evidence of the conservation risks of building the dam).

Some Trio are also wary of ACT's work, wondering what their interest is-does Mark Plotkin, ACT's charismatic leader, plan to take the resources for himself? ACT's activities are also the cause of some tension because they are felt by some to be ungenerous since they pay small salaries and only recruit a handful of individuals. Not only do these individuals benefit from a small but not insignificant income but also their knowledge is privileged when maps of resource use are created. If ACT's maps are as inadequate as the Forest Peoples' Programme (FPP 2013) and VIDS suggest (a judgement not entirely free from political motivations), then these are likely to be among the underlying reasons. ${ }^{12}$

Valuation surveys for the purposes of land claims and REDD+ involve a complex and often tense set of interactions between technicians and Amerindians. At the end of these interactions, it seems that both parties remain with their assumptions and worldviews more or less intact. Yet the solutions that emerge and the nature of the activities in which they collaborate often do not meet the expectations of either party. When Asonko suggested creating a farm, he may have imagined himself becoming a kind of supreme master of animals, an image likely to have been inspired by missionary teaching which has encouraged the view that Jesus is the master of all beings and that he benevolently condones the unlimited hunting of all food species. The CI director saw the potential for a collaboration on a community-managed, restricted hunting area, an important experiment which could support her advocacy of community-managed conservation areas vis-à-vis the government.

Perhaps we should interpret this as an example of 'equivocal compatibility' (De Piña Cabral 2005) or a 'working misunderstanding' (Sahlins 1982) as Trio people become involved in conservation and mapping activities for reasons of their own, and serendipitous results emerge, sometimes to the satisfaction of all concerned, if not quite in the ways they expected. But I think that what is going on is a little more complicated. As I have mentioned, for Trio people, the process of mapping for demarcation raises suspicion because they recognise that the land is being subjected to a process of measurement for the sake of appropriation. According to the Trio's own 
anthropology of white people, measurement and appropriation are closely linked, and they are not far wrong (cf. Stensrud, this volume). Even though the NGO workers regard the Trio themselves as the beneficiaries of this process, there is a sense in which the process itself dispossesses them. The land becomes property under a regime foreign to the Trio, even if it is legally theirs - the legal system in question is not their own. Meanwhile, the technological removal of ambiguity in property relations ensures that there will be tension, and that the ultimate arbiter of that tension will be the state, which will thus have an opportunity to reassert its authority. This helps answer the question of whether the marketisation of carbon and biodiversity can be understood as a process of resource extraction: while it does not involve the physical extraction of resources from the environment, it does involve an act of appropriation through the imposition of different categories of knowledge and ownership: a kind of cross-cultural extraction of wealth. It is thus only in this limited sense that it contributes to the commodification of new areas of life in the form of biodiversity.

\section{Conclusion}

This last observation begs the question: do more formal, technical forms of knowledge and ownership (what James Leach [2016] calls 'property' as opposed to 'ownership'), therefore, always necessarily overcome or disrupt more relational modes of knowing and owning? The following example may suggest that they do: near the Tapanahoni river, there is a tepui mountain which has mythical associations for both the Wayana (Caribspeaking neighbours of the Trio) and for the Ndjuka Maroons. For the Wayana, it is a place of origin and a place of the dead: it is a tukusipan, an architypal house. For the Ndjuka, it is a sacred site associated with ancestral spirits. The Wayana and Ndjuka fought a war against each other in the nineteenth century, but they finally made peace, and, according to the Wayana's version of events, the leaders of the two warring groups drank each other's blood to seal their peace. Having established shared substance through this ritual gesture, they agreed to respect the limits of their respective territories. Their cohabitation was made easier by the ambiguity in the precise boundaries of these territories, such that the tepui in question did not become the exclusive property of either group. Now, however, both Wayana and Ndjuka territories have been mapped with a view to obtaining official state demarcation of ancestral lands. This has given rise to a dispute over who owns the sacred mountain. ${ }^{13}$ 
In this case, there was no great equivocation over what was going on when the mapping process was carried out. Amerindian and Maroon guides worked for ACT to produce maps of their traditional resources, including places of ritual or mythical importance. However, the value of land for the Wayana and Ndjuka was not based on its value as a commodity, and the mapping process treated cultural property as though it were just that. For this reason, the result of a fairly smooth technical collaboration was the revelation of the incompatibility of two regimes of value.

Nevertheless, the codes of ownership and knowledge that are woven by formal extractive techniques can also provide a space for dialogue once they have been given time to establish themselves as a common language. Indeed, the interactions between CI and ACT with the Trio gradually overcame some of the latter's scepticism, and in 2016 Granman Asonko finally agreed on behalf of all the Trio to cooperate with the REDD+ 'readiness' process (SurinameREDD 2016). Without presuming to judge whether or not he made the 'right' decision, the point worth noting here is that the Trio could see a mutual interest in REDD+ for themselves and the technocratic 'white' outsiders, establishing a partial connection with the latter and partially adopting their ways of knowing in a 'both and' move similar to that described by Guzmán-Gallegos (this volume). This contrasts with both forms of primary resource extraction: formal, industrial mining and logging and informal placer mining for gold. What distinguishes these from carbon and biodiversity is not only their physical (rather than virtual) mode of extraction but also the related fact that they treat the forest as a wild frontier, a resource frontier-an attitude incompatible with the Trio's cosmology and livelihood. Carbon and biodiversity valuation, on the other hand, treat the forest environment as a world of complex socioenvironmental interactions, and practitioners share this approach with the Trio despite their differing epistemology and techniques.

\section{NoTes}

1. Timber, of course, cuts across the categories of conventional primary resources, forest carbon, and biodiversity and can be qualified and quantified in terms of any of all these categories.

2. Maroons are descendants of Africans who escaped Dutch slave plantations as early as the eighteenth century. Suriname has the largest maroon community in the Western hemisphere including six tribes: the Djuka or Ndjuka and the Saramaka (each 15,000-20,000 people); the Matawai, the 
Aluku and the Paramaka (each around 2000), and the Kwinti (fewer than 500) (Price 1976: 3-4). Greatly outnumbering the Amerindian population upstream, they dominate the middle reaches of the Saramacca, Suriname, and Maroni rivers and the lower parts of the Tapanahoni and Lawa, tributaries of the Maroni.

3. I have carried out nearly two years of field research in Suriname and neighbouring French Guiana since 2002, the majority of which was conducted among the Trio, Wayana, and Akuriyo.

4. To consider indigenous forms of property relations as common property regimes has the advantage of recognising many of the most important implications of their distinction from private property regimes but greatly simplifies their structural features and mode of functioning, especially their processual and situational aspects (Brightman et al. 2016).

5. There is a vast and growing critical literature on REDD+ (reduce emissions from deforestation and forest degradation in developing countries). For a summary, see Hufty and Haakenstad (2011). See also (Burnham 2012; Dooley et al. 201 1; Kricheff 2012; Pokorny et al. 2013; Rival 2013; Smith 2010; Sullivan 2013; The Munden Project 2011; Van Dam 2011).

6. An opportunity cost is 'a benefit, profit, or value of something that must be given up to acquire or achieve something else' (Business Dictionary n.d.).

7. The role of cosmological owners in Amazonia may be compared with that of 'earth-beings' in Andean societies (see Stensrud, this volume).

8. The importance of historical processes in the constitution of ownership relations and 'ontogeny' is eloquently discussed in an Andean context by Rivera Andía (this volume).

9. Similar processes have been described in Andean ethnography (Rivera pers. comm. 3 November 2017).

10. It is useful to distinguish between formal, usually private property regimes and relational regimes of ownership such as those of native Amazonian and Melanesian peoples. James Leach distinguishes these by reserving the term 'property' for the former and using the term 'ownership' to include the latter (Leach 2011; Brightman et al. 2016).

11. For further discussion of this topic, see Brightman (2012). For a comparable argument among a neighbouring people, see Mentore (2011). For relevant theoretical discussion, see Casey (1996).

12. Some management difficulties with ACT's (Amazon Conservation Team) Suriname programme during the period in question may also be partly to blame (M. Plotkin pers. comm. 2015).

13. Not all Ndjuka or Wayana are in agreement over whether or not there is, in fact, a dispute. One Ndjuka leader assured me that the two groups concerned are managing these changes amicably. 


\section{REFERENCES}

Adams, William. 1990. Green Development: Environment and Sustainability in the Third World. London: Routledge.

Barman, Emily. 2015. Of Principle and Principal: Value Plurality in the Market of Impact Investing. Valuation Studies 3 (1): 9-44.

Brightman, Marc. 2010. Creativity and Control: Property in Guianese Amazonia. Journal de la Société des Américanistes 96 (1): 135-167.

. 2012. Maps and Clocks in Amazonia: The Things of Conversion and Conservation. Journal of the Royal Anthropological Institute 18 (3): 554-571.

- 2014. Audit Sauvage: Régimes de valeur de la terre et de la biodiversité en Amazonie. Ethnographique(s) 27 (online journal). Available at http://www. ethnographiques.org/2013/Brightman. Accessed 15 Feb 2018.

_. 2016a. Esperança e Compatibilidade Equívoca na Governança da Floresta: REDD+e os Direitos Sobre a Terra Indígenas e Tribais no Suriname. RURIS 10 (1): 219-254.

. 2016b. The Imbalance of Power: Leadership, Masculinity and Wealth in the Amazon. New York: Berghahn.

Brightman, Marc, Carlos Fausto, and Vanessa Grotti, eds. 2016. Ownership and Nurture. Studies in Native Amazonian Property Relations. New York/Oxford: Berghahn Books.

Burnham, Philip. 2012. Climate Change and Forest Conservation: A REDD Flag for Central African Forest People? In Climate Change and Indigenous Knowledge: Perceptions and Adaptations of Threatened Communities, ed. David Brokensha, Peter Castro, and Dan Taylor. Rugby: Practical Action Publishing.

Business Dictionary. n.d. http://www.businessdictionary.com/definition/ opportunity-cost.html. Accessed 21 Oct 2017.

Callon, Michel. 2009. Civilizing Markets: Carbon Trading Between In Vitro and In Vivo Experiments. Accounting, Organizations and Society 34 (3): 535-548.

Callon, Michel, and Fabian Muniesa. 2005. Peripheral Vision: Economic Markets as Calculative Collective Devices. Organization Studies 26 (8): 1229-1250.

Casey, Edward. 1996. How to Get from Space to Place in a Fairly Short Stretch of Time: Phenomenological Prolegomena. In Senses of Place, ed. Steven Feld and Keith Basso. Santa Fe: School of American Research Press.

Chapin, Mac. 2004. A Challenge to Conservationists. World Watch Magazine 17 (6): 17-31.

Costa, Luiz. 2010. The Kanamari Body-Owner. Predation and Feeding in Western Amazonia. Journal de la Société des Américanistes 96 (1). http://jsa.revues. org/11332. Accessed 9 Oct 2013.

- 2012. Making Animals into Food Among the Kanamari of Western Amazonia. In Animism in Rainforest and Tundra: Personbood, Animals and Nonhumans in Contemporary Amazonia and Siberia, ed. Marc Brightman, Vanessa Grotti, and Olga Ulturgasheva. New York/Oxford: Berghahn. 
De Piña Cabral, João. 2005. Between China and Europe: Person, Culture and Emotion in Macao. London: Continuum.

Descola, Philippe. 1992. Societies of Nature and the Nature of Society. In Conceptualizing Society, ed. Adam Kuper. London: Routledge.

Dooley, Kate, Tom Griffiths, Francesco Martone, and Saskia Ozinga. 2011. Smoke and Mirrors: A Critical Assessment of the Forest Carbon Partnership Facility. Moreton-in-Marsh: FERN and Forest Peoples Programme.

Engle, Karen. 2010. The Elusive Promise of Indigenous Development: Rights, Culture, Strategy. Durham: Duke University Press.

FAO. 2010. Global Forest Resources Assessment 2010. Country Report: Suriname. Rome: Food and Agriculture Organisation of the United Nations.

Fausto, Carlos. 2008. Donos Demais. Maestria e Domínio na Amazônia. Mana $14(2): 329-366$.

FPP. 2012. The Return of Fortress Conservation: REDD and the Green Land Grab in the Peruvian Amazon. https://www.forestpeoples.org/en/topics/ redd-and-related-initiatives /news / 2012/10/return-fortress-conservationredd-and-green-land-gr. Accessed 19 Dec 2017.

- 2013. Comments on Suriname RPP (23 February 2013). http://www. forestpeoples.org. Accessed 3 Apr 2013.

Graeber, David. 2001. Toward an Anthropological Theory of Value: The False Coin of Our Own Dreams. New York: Palgrave.

Grotti, Vanessa. 2007. Nurturing the Other: Wellbeing, Social Body and Transformability in Northeastern Amazonia. PhD Dissertation, Cambridge University.

Hann, Chris, ed. 1998. Property Relations: Renewing the Anthropological Tradition. Cambridge, UK: Cambridge University Press.

Hufty, Marc, and Annie Haakenstad. 2011. Reduced Emissions for Deforestation and Degradation: A Critical Review. Consilience 5 (1): 1-24.

IUCN. 2012. REDD+ Explained. www.iucn.org. Accessed 22 Aug 2012.

Jolivet, Marie-José. 2007. Approche anthropologique du multiculturalisme guyanais: Marrons et créoles dans l'Ouest. In Pratiques et représentations linguistiques en Guyane: Regards croisés, ed. Isabelle Léglise and Bettina Migge. Paris: IRD Éditions.

Kambel, Ellen-Rose, and Fergus Mackay. 1999. The Rights of Indigenous Peoples and Maroons in Suriname. Copenhagen: IWGIA.

Kricheff, Daniel. 2012. Market Environmentalism and the Re-animation of Nature. Radical Anthropology 6: 17-25.

Kruijt, Dirk, and Wim Hoogbergen. 2005. Peaceful Relations in a Stateless Region: The Post-War Maroni River Borders in the Guianas. Tijdschrift voor Economische En Sociale Geografie 96 (2): 199-208.

Leach, James. 2011. The Problem of Property in Customary Tenure: An Example from Papua New Guinea. Paper presented at The Value of Land, Lisbon, 9-10, September. 
2016. Foreword. In Ownership and Nurture: Studies in Native Amazonian Property Relations, ed. Marc Brightman, Carlos Fausto, and Vanessa Grotti. New York: Berghahn.

Maris, Virginie. 2010. Philosophie de la biodiversité: petite éthique pour une nature en péril. Paris: Buchet/Chastel.

Mentore, Laura. 2011. Waiwai Fractality and the Arboreal Bias of PES Schemes in Guyana: What to Make of the Multiplicity of Amazonian Cosmographies? Journal of Cultural Geography 28 (1): 21-43.

Namati. 2015. Decision Details: Kaliña and Lokono Peoples v. Suriname. https:// namati.knack.com/casebase\#searchcases/decisiondetails2/57dc496c904df7a $1767 \mathrm{dlfd} 2 /$. Accessed 16 Oct 2017.

Olson, David, and Eric Dinerstein. 1998. The Global 200: A Representation Approach to Conserving the Earth's Most Biologically Valuable Ecoregions. Conservation Biology 12: 502-515.

Orellana, Marcos. 2008. Saramaka People v. Suriname. The American Journal of International Law 102 (4): 841-847.

Plotkin, Mark. 1994. Tales of a Shaman's Apprentice: An Ethnobotanist Searches for New Medicines in the Amazon Rain Forest. London: Penguin.

Pokorny, Benno, Imme Scholz, and Wil De Jong. 2013. REDD+ for the Poor or the Poor for REDD+? About the Limitations of Environmental Policies in the Amazon and the Potential of Achieving Environmental Goals Through ProPoor Policies. Ecology and Society 18 (2): 3.

Posey, Darrell, and William Balée, eds. 1989. Resource management in Amazonia: Indigenous and Folk Strategies. New York: New York Botanical Garden.

Price, Richard. 1976. The Guiana Maroons: A Historical and Bibliographical Introduction. Baltimore: Johns Hopkins University Press.

- 2011. Rainforest Warriors: Human Rights on Trial. Philadelphia: University of Pennsylvania Press.

Rival, Laura. 2002. Trekking Through History: The Huaorani of Amazonian Ecuador. New York: Columbia University Press.

- 2013. From Carbon Projects to Better Land-Use Planning: Three Latin American Initiatives. Ecology and Society 18 (3): 17.

Rivière, Peter. 2001. A predação, a reciprocidade e o caso das Guianas. Mana 7 (1): 31-53.

Sachs, Jeffrey. 2015. The Age of Sustainable Development. New York: Columbia University Press.

Sahlins, Marshall. 1982. The Apotheosis of Captain Cook. In Between Belief and Transgression: Structuralist Essays in Religion, History and Myth, ed. Michel Izard and Pierre Smith. Chicago: University of Chicago Press.

Smith, Gwendolyn. 2010. Carbon-Based Conservation Projects in Traditional Communities in Ecuador and Suriname: An Analysis of Vulnerability and Conflict Potential. Peace and Conflict Review 5 (1): 1-10. 
Sommerville, Matt. 2011. Land Tenure and REDD+: Risks to Property Rights and Opportunities for Economic Growth. Property Rights and Resource Governance Issue Paper \#11. USAID.

Sullivan, Sian. 2013. Banking Nature? The Spectacular Financialisation of Environmental Conservation. Antipode 45 (1): 198-217.

SurinameREDD. 2016. Krutu at Kwamalasamutu http://www.surinameredd.org/ en/news/events/2016/krutu-at-kwamalasamutu/. Accessed 16 Oct 2017.

Taylor, Anne-Christine. 1993. Remembering to Forget: Identity, Mourning and Memory Among the Jivaro. Man (N.S.) 28 (4): 653-678.

The Munden Project. 2011. REDD and Forest Carbon: Market-Based Critique and Recommendations. www.themundenproject.com. Accessed 24 May 2013.

Van Dam, Chris. 2011. Indigenous Territories and REDD in Latin America: Opportunity or Threat? Forests 2: 394-414.

Westra, Laura. 2008. Environmental Justice and the Rights of Indigenous Peoples. London: Earthscan.

Open Access This chapter is licensed under the terms of the Creative Commons Attribution 4.0 International License (http://creativecommons.org/licenses/ by $/ 4.0 /)$, which permits use, sharing, adaptation, distribution and reproduction in any medium or format, as long as you give appropriate credit to the original author(s) and the source, provide a link to the Creative Commons license and indicate if changes were made.

The images or other third party material in this chapter are included in the chapter's Creative Commons license, unless indicated otherwise in a credit line to the material. If material is not included in the chapter's Creative Commons license and your intended use is not permitted by statutory regulation or exceeds the permitted use, you will need to obtain permission directly from the copyright holder.

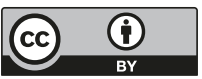

